\title{
PERAN SAKTI PEKSOS DALAM MENDAMPINGI ANAK-ANAK TERLANTAR (SUDUT PANDANG TEORI SOCIAL LEARNING) DI DINAS SOSIAL KABUPATEN GUNUNG KIDUL
}

\author{
Vikri Rahmaddani \\ Universitas Islam Negeri Sunan Kalijaga Yogyakarta \\ e-mail:vikrirahmaddani3006@gmail.com
}

\begin{abstract}
Child social welfare can be fulfilled with Child Social Welfare Program (PKSA), which this program has been implemented by social office of GunungKidul regency which in its implementation can not be separated from the role of a social worker. In this child social welfare program does not separate the child from the family, but the child lives with the family, so the model of accompaniment in doing social work from the social service is insindental (at any time) when needed to assist the client. The formulation of the problem is how the role of social work through Child Social Welfare Program (PKSA) which is implemented by the Social Service of GunungKidul Regency, and what are the social worker barriers in implementing Child Social Welfare Program (PKSA) implemented by Social Service of GunungKidul Regency In general, this study is a development of research through qualitative descriptive approach, to obtain an accurate process in conducting research on the role of Social Worker In Accompanying Neglected Children (Viewpoint of Social Learning Theory), the authors determine informants from relevant stakeholders, consisting of government in social offices or related institutions and Saktipeksos. In this study the authors determine the informants by purposive sampling technique, which means choosing a deliberately chosen informant who taknib because there are considerations to achieve certain goals. So they can provide the right input about the accompaniment in the process carried out. Methods of data collection used are interviews, observation, and documentation. After the data collected, the next step the authors determine the technique of data validation, while the selected technique is keajengan observation with the intention of finding the characteristics and elements in situations that are very relevant to the issues and issues sought, then focus than on those things detailed. With this the authors only make observations to the problem in the precise is the role of SaktiPeksos in assisting children abandoned with Social Learning Theory.
\end{abstract}

Keywords: Child Social Welfare Program (PKSA), Social Work, Government Policy.

\section{Pendahuluan}

Program Kesejahteraan Sosial Anak adalah upaya yang terarah, terpadu dan berkelanjutan yang di lakukan pemerintah dan masyarakat dalam bentuk pelayanan sosial untuk memenuhi kebutuhan dasar anak meliputi subsidi kebutuhan dasar, aksebilitas pelayanan sosial, penguatan orang tua atau keluarga dan lembaga kesejahteraan sosial anak. Program Kesejahteraan Sosial Anak (PKSA) menjadi prioritas nasional Kementrian 
Sosial RI untuk mewujudkan pemenuhan hak dasar anak dan perlindungan terhadap anak dari penelantaran, eksploitasi dan diskriminasi. ${ }^{30}$

Setiap anak mempunyai hak yang sama untuk hidup, tumbuh dan berkembang secara maksimal sesuai potensinya. Secara berlapis, dimulai dari lingkar keluarga dan kerabat, masyarakat sekitar, pemerintah lokal hingga pemerintah pusat, hingga masyarakat internasional berkewajiban untuk menghormati, melindungi, dan mengupayakan pmemenuhan atas hak-hak anak tersebut. Hanya jika setiap lapisan pemangku tugas tersebut dapat berfungsi dengan baik dan mampu menjalankan kewajiban dan tanggung jawabnya, maka anak akan dapat memiliki kehidupan berkualitas yang memungkinkannya tumbuh kembang secara optimal sesuai potensinya. ${ }^{31}$

Masyarakat dan pemerintah dari berbagai tingkatan telah melakukan berbagai layanan dan program yang terus dikembangkan dengan intensitas dan kualitas yang diupayakan terus meningkatkan dari tahun ke tahun. Namun faktanya masih sangat banyak anak yang belum tersentuh pelayanan kesejahteraan sosial karena keterbatasan sumber daya, keterbatsan cakupan pelayanan ini disertai dengan belum adanya keterpanduan perencanaan dan pengelolaan sumber daya dan layanan diantara lembagalembaga pelayanan sosial yang ada. Keterbatasan tersebut juga diperparah dengan penggunaan pendekatan dan strategi yang konvensional, sehingga mengakibatkan meningkatnya masalah sosial anak yang tidak dapat diimbangi dengan upaya pencegahan dan respon yang memadai. Strategi konvensional dimaksud seperti kurangnya memperhatikan kebutuhan dasar anak yang beragam, sehingga bantuan sosial cenderung diseragamkan.

Namun kesejahteraan sosial anak sepenuhnya belum terlayani, seperti hak memperoleh kebutuhan dasar yaitu (sandang, pangan, papan). Padahal anak adalah penentu majunya suatu negara yang dapat dilihat dari kondisi anak sekarang ini, bila kondisi anak sekarang ini sudah mulai tidak terlayani kebutuhannya, maka majunya suatu negara tidak akan berkembang, melainkan akan melahirkan generasi-generasi perusak bangsa. Dengan hal tersebut, maka pelayanan hak anak harus ditingkatkan sepaya nilai gunanya tinggi. Pada tahun 2009 Program Kesejahteraan Sosial Anak (PKSA) mulai dikembangkan dan diujicobakan untuk kesejahteraan sosial anak yang utamanya

\footnotetext{
${ }^{30} \mathrm{http}: / /$ dinsos.jogjaprov.go.id/program-kesejahteraan-sosial-anak/,/di unduh pada tanggal 6 januari 2017

${ }^{31}$ Pedoman Operasional Program Kesejahteraan Sosial Anak (PKSA), Direktorat Kesejahteraan Sosial Anak, Direktorat Jenderal Rehabilitas Sosial, Kementerian Sosial RI,Hlm VI
} 
pendidikan bagi anak yang putus sekolah bisa sekolah, PKSA diujicobakan di lima wiilayah yaitu Jawa Barat, DKI Jakarta, Lampung, Sulawesi Selatan, dan Yogyakarta.

Undang-Undang No 4 Tahun 1979 tentang kesejahteraan anak, menjelaskan bahwa kesejahteraan anak adalah suatu tata kehidupan dan pengidupan anak yang dapat menjamin pertumbuhan dan perkembangan dengar wajar, baik secara rohani, jasmani mapun sosial. Namun demikian, pemeliharaan kesejahteraan anak belum dapat dilakukan oleh anak sendiri sehingga tanggung jawab tersebut terjadi tanggungan orang tua, keluarga, masyrakat dan pemerintah (UU No. 4 Tahun 1979). ${ }^{32}$ Orang tua dan keluarga memiliki tanggung jawab pertama terhadap kesejahteraan anak karena keluarga merupakn kelompok sosial pertama dalam kehidupan anak untuk tumbuh dan berkembang. Hal-nya dalam berkeluarga, penyingkapan orangtua terhadap anak dipenagruhi oleh persepsi orang tua terhadap arti anak. Bagi orang tua, anak dapat dilihatbsebagai komoditas rumah tangga yang memiliki fungsi konsumsi, investasi dan asuransi. ${ }^{33}$

Selain itu tercantum dalam UU RI No. 23 Tahun 2002 pasal 1 Tentang Perlindungan Anak disebutkan bahwa anak adalah seseorang yang belum berusia 18 tahun termasuk anak yang ada di dalam kandungan. Sedangkan menurut UU Kesejahteraan Anak di dalam pasal 1 ayat 2 menyatakan bahwa anak adalah seseorang yang berusai 21 tahun atau anak yang belum menikah. ${ }^{34}$ Salah satu bentuk tanggung jawab pemerintah dalam kesejahteraan sosial anak adalah adanya Program Kesejahteraan Sosial Anak (PKSA) yang dilaksanakan oleh Kementerian Sosial RI tujuannya adalah upaya yang terarah, terpadu dan berkelanjutan. Bentuk pelayanan sosial untuk memenuhi kebutuhan dasar anak meliputi subsidi kebutuhan dasar, aksebilitas pelayanan sosial, penguatan orang tua, keluarga dan lembag kesejahteraan sosial anak. Dalam pelaksanaan PKSA diperlukan peran masyarakat yang seluas-luasnya, baik perseorangan, keluarga, oraganisasis keagamaan, oraganisasi sosial kemasyarakatan, lembaga swadaya masyarakat, organisasi profesi, badan usaha, lembaga kesejahteraan sosial, maupun lembaga kesejahteraan sosial asing demi terselenggaranya kesejahteraan sosial terarah, terpadu, dan berkelanjutan.

Pekerja Sosial adalah seseorang yang melakukan aktifitas profesional untuk menolong individu, kelompok dan masyarakat dalam meningkatkan atau memperbaiki

\footnotetext{
${ }^{32}$ Undang-Undang Rebuplik Indonesia Nomor 4 Tahun 1979 tentang Kesejahteraan Anak.

${ }^{33}$ Nurvidya dan Wongkaren, Pedoman Penanganan Masalah Sosial, (Bandung Sinar Bari Algesindo, 1997) HLM.3

${ }^{34}$ Undang-Undang Republik Indonesia Nomor 23 Tahun 2002 tentang Perlindungan Anak, pasal 1 ayat 3
} 
kapasitas mereka agar berfungsi sosial dan menciptakan kondisi-kondisi masyarakat yang kondusif untuk mencapai tujuannya tersebut. ${ }^{35}$ Menurut Undang-Undang No. 11 Tahun 2009 tentang kesejahteraan sosial, yang dimaksud pekerja sosial adalah seseorang yang bekerja, baik di lembaga pemerintah maupun swasta yang memiliki kompetensi dan profesi pekerjaan sosial, dan kepedulian dalam pekerjaan sosial yang di peroleh melalui pendidikan, pelatihan, dan pengalaman praktek pekerjaan sosial untuk melakukan tugastugas pelayanan dan penanganan masalah sosial. ${ }^{36}$

Adanya permasalahan terhadap anak yang terlantar berdampak pada peningkatan kriminalitas pada masyarakat. Maka fokus penelitian di ini adalah : Bagaimana peran pekerjaan sosial melalui Program Kesejahteraan Sosial Anak (PKSA) yang di laksanakan oleh Dinas Sosial Kabupaten Gunung Kidul, serta apa hambatan Pekerja sosial dalam melaksanakan Program Kesejahteraan Sosial Anak (PKSA) yang dilaksanakan oleh Dinas Sosial Kabupaten Gunung Kidul, dari fokus tersebut mempunyai tujuan untuk mengetahui bagaimana peran Satuan Bakti Pekerja Sosial (Sakti Peksos) dalam melaksanakan Program Kesejahteraan Sosial Anak (PKSA).

Adapun salah satu teori ataupun skill yang dapat di gunakan Sakti Peksos dalam mendampingi anak-anak terlantar adalah Teori Social Learning (Pembelajaran Sosial), yang mana teori ini mengatakan bahwa orang dapat mempelajari informasi baru dan perilaku dengan cara melihat orang lain (belajar observasional). Konsep dasar dari teori ini adalah bahwa orang-orang dapat belajar melalui observasi atau pengamatan, kemudian dilanjutkan dengan peniruan. Mereka mengubah perilakunya melalui penyaksian terhadap bagaimana orang lain merespon sebuah stimulus tertentu. Teori ini menjelaskan bagaimana kita dipengaruhi dan mempengaruhi lingkungan melalui penguat dan pembelajaran observasional yang intinya teori ini adalah mengamati, meniru dan mempraktekkan. ${ }^{37}$ Jadi sakti peksos melakukan implementasi teori ini dengan cara memberikan gambaran bahwa diluar sana banyak anak-anak yang berprestasi karena rajin sekolah, membaca buku, unggul dalam seni dan lain-lain, serta itu anak juga harus kita support dan terus kita dorong untuk mengarah kepada hal-hal yang positif agar nantiknya anak ini memiliki visi misinya kedepan lebih mempunyai tujuan yang positif lagi.

\footnotetext{
${ }^{35}$ Miftahul Huda, Pekerjaan Sosial Dan Kesejahteraan Sosial, (Yogyakarta Pustaka Pelajar, 2009), Hlm, 3

${ }^{36}$ Undang-Undang Republik Nomor 11 Tahun 2009 Tentang Kesejahteraan Sosial, Hlm, 3

${ }^{37}$ http://ginakesos.blogspot.co.id/2012/09/
} 
Dari perpaduan teori dan praktek diatas, maka artikel ini akan membahas mengenai bagaimana proses Sakti Peksos dalam menerapkan teori social learning di dalam mendampingi anak-anak yang bermasalah. Dengan harapan, hasil kajian ini diharapkan menjadi referensi bagaimana untuk mengetahui peran Sakti Peksos di dalam mengaplikasikan teori social learning, dan bisa diterima dengan baik tidak menyudutkan anak-anak yang bermasalah, namun sebagai solusi untuk mereka bisa hidup lebih baik lagi untuk dirinya sendiri dan keluarga khususnya, begitu juga untuk bangsa dan negara pada umunya.

Secara umum, kajian ini merupakan pengembangan riset melalui pendekatan deskriftif kualitatif, untuk memperoleh proses yang akurat dalam melakukan penelitian tentang Peran Sakti Peksos Dalam Mendampingi Anak-anak Terlantar (Sudut Pandang Teori Social Learning), penulis menentukan informan dari stakeholder yang terkait, yang terdiri dari pemerintah di dinas sosial atau lembaga yang terkait dan Sakti peksos. Dalam kajian ini penulis menentukan informan dengan teknik purposive sampling, artinya memilih informan yang dipilih secara sengaja yang diamnbil karena ada pertimbangan untuk mencapai tujuan-tujuan tertentu. ${ }^{38}$ sehingga mereka dapat memberikan masukan secara tepat tentang proses pendampingan yang di laksanakan. Metode pengambilan data yang digunakan adalah wawancara, observasi, dan dokumentasi. Setelah data terkumpul, langkah selanjutnya penulis menentukan teknik validasi data, adapun yang dipilih adalah teknik Keajengan pengamatan dengan maksud menemukan ciri-ciri dan unsur-unsur dalam situasi yang sangat relevan dengan persoalan dan isu yang dicari, kemudian memusatkan dari pada hal-hal tersebut secara rinci. Dengan hal ini penulis hanya melakukan pengamatan kepada masalah yang di teliti yaitu Peran Sakti Peksos dalam mendampingi anak-anak terlantar dengan Teori Social Learning.

\section{Program Kesejahteraan Sosial Anak}

Kemeterian Sosial telah menindaklanjuti dan telah merumuskan Rencana Strategis Pelayanan Kesejahteraan Sosial Anak 2010-2014 dan menjadi dasar acuan utama dengan di tetapkannya Program Kesejahteraan Sosial Anak (PKSA) yang di tetapkan melalui Keputusan Menteri Republik Indonesia No.15 A/HUK/2010. Program Kesejahteraan Sosial Anak (PKSA) adalah upaya yang terarah, terpadu, dan berkelanjutan oleh pemerintah, pemerintah daerah, dan masyarakat dalam bentuk pelayanan sosial guna

\footnotetext{
${ }^{38}$ Sugiyono, Memahami Penelitian Kualitatif, h.52
} 
memenuhi kebutuhan dasar anak. Layanan sosial yang diberikan dalam PKSA antara lain : 1) subsidi kebutuhan dasar anak, 2) peningkatan aksesibilitas terhadap pelayanan sosial dasar (aktekelahiran, pendidikan, kesehatan, dll), 3) penguatan tanggung jawab orangtua atau keluarga dalam pengasuhan anak. ${ }^{39}$

\section{Tujuan Program Kesejahteraan Sosial Anak}

Tujuan PKSA menurut Rencana Strategis Pelayanan Kesejahteraan Sosial Anak adalah terwujudnya pemenuhan hak dasar anak dan perlindungan terhadap anak dari penelantaran, eksploitasi, dan diskriminasi sehingga tumbuh kembang, kelangsungan hidup, dan partisipasi anak dapat terwujud. Kriteria anak yang mendapatkan bantuan PKSA antara lain: 1) anak balita terlantar dan membutuhkan perlindungan khusus, 2) anak terlantar tanpa pengasuhan orangtua, 3) anak terpaksa bekerja di jalan, 4) anak yang berhadapan dengan hukum, 5) anak dengan kecacatan, 6) dan anak yang memerlukan perlindungan khusus lainnya.Kriteria Penerima Program. Penerima manfaat program ini diprioritaskan kepada anak-anak yang memiliki kehidupan yang tidak layak secara kemanusiaan dan memiliki kriteria masalah sosial seperti kemiskinan, ketelantaran, kecacatan, keterpencilan, ketunaan sosial dan penyimpangan perilaku, korban bencana, dan/atau korban tindak kekerasan, eksploitasi dan diskriminasi.penguatan kelembagaan kesejahteraan sosial anak. ${ }^{40}$

\section{Kriteria Penerima Manfaat}

Sasaran PKSA diprioritaskan kepada anak yang memiliki kehidup-an yang tidak layak secara kemanusiaan dan memiliki kriteria masalah sosial seperti kemiskinan, ketelantaran, kecacatan, keterpencilan, ketunaan sosial dan penyimpangan perilaku, korban bencana, korban tindak kekerasan, korban eksploitasi dan diskri-minasi. Sasaran penerima manfaat dibagi dalam 6 (enam) kelompok, yaitu :

A. Anak balita telantar (usia 0 sampai dengan dibawah 5 tahun), meliputi :

1. Anak yang berasal dari keluarga sangat miskin/miskin.

2. Anak yang kehilangan hak asuh dari orangtua/ keluarga.

3. Anak yang mengalami perlakuan salah dan ditelantarkan oleh orang tua/ keluarga.

\footnotetext{
${ }^{39}$ Direktorat, kesejahteraan sosial anak, 2011. Pedoman operasional program kesejahteraan sosial anak. Jakarta : Kementerian Sosial Republik Indonesia.

${ }^{40}$ http://pksa.kemsos.go.id
} 
4. Anak yang di eksploitasi secara ekonomi seperti anak balita yang disalahgunakan orang tua menjadi pengemis di jalanan.

5. Anak yang menderita gizi buruk atau kurang

B. Anak telantar (usia 5 sampai dengan 18 tahun), meliputi :

1. Anak yang mengalami perlakuan salah dan ditelantarkan oleh orang tua/ keluarga.

2. Anak kehilangan hak asuh dari orang tua/ keluarga.

C. Anak terpaksa bekerja di jalanan (6 sampai dengan 18 tahun), meliputi:

1. Anak yang bekerja dan hidup di jalanan.

2. Anak yang bekerja di jalanan.

3. Anak yang rentan bekerja di jalanan.

D. Anak berhadapan dengan hukum(6 sampai dengan 18 tahun), meliputi :

1. Anak diindikasikan melakukan pelanggaran hukum.

2. Anak yang mengikuti proses peradilan.

3. Anak yang menjadi korban perbuatan pelanggaran hukum.

4. Anak yang menjadi saksi tindak pidana.

5. Anak yang berstatus diversi.

6. Anak yang telah menjalani masa hukuman pidana.

E. Anak dengan disabilitas (0 sampai dengan 18 tahun), meliputi :

1. Mampu latih dan mampu didik

2. Disabilitas ringan dan sedang, meliputi : Anak dengan disabilitas fisik; Anak dengan disabilitas mental, Anak dengan disabilitas fisik dan mental

3. Anak dengan disabilitas berat yang belum diakses Asistensi Sosial Orang dengan Kecacatan Berat.

F. Anak yang memerlukan perlindungan khusus lainnya (0 sampai dengan 18 tahun), meliputi :

1. Anak dalam situasi darurat dan berada dalam lingkungan yang buruk/ diskriminasi.

2. Anak korban perdagangan manusia.

3. Anak korban kekerasan, baik fisik dan/atau mental dan seksual.

4. Anak korban eksploitasi ekonomi atau seksual. 
5. Anak dari kelompok minoritas dan terisolasi serta dari komu--ni--tas adat terpencil.

6. Anak yang menjadi korban penyalahgunaaan narkotika, alkohol, psikotropika dan zat adiktif lainnya (NAPZA).

7. Anak yang terinfeksi HIV/AIDS. ${ }^{41}$

\section{Persyaratan Dan Kewajiban Penerima Manfaat/Layanan}

Persyaratan dan kewajiban penerima manfaat/layanan sasaran penerima layanan PKSA, baik anak, orang tua/keluarga maupun lembaga kesejahteraan sosial yang menjadi mitra pendamping harus memenuhi persyaratan (conditionalities) sebagai berikut :

1. Adanya perubahan sikap dan prilaku (fungsi sosial) ke arah positif.

2. Intensitas kehadiran dalam layanan sosial dasar dari berbagai organisasi/lembaga semakin meningkat.

3. Peran lembaga kesejahteraan sosial anak yang bermitra dengan instansi sosial dalam mendampingi anak sehingga anak dapat terhindar dari penelantaran, eksploitasi, kekerasan dan diskriminasi.

\section{Kerangka Kerja Konseptual PKSA}

Kerangka kerja konseptual merupakan upaya peningkatan kesejahteraan dan perlindungan anak berbasis keluarga yang dilaksanakan berdasarkan proses sosial, assesment masalah dan kebutuhan anak, termasuk orang tua/keluarga dan lingkungan sosial. Direktorat Rehabilitasi Sosial Anak Kemensos menugaskan Sakti Peksos dalam pendampingan penyelesaian permasalahan anak meliputi Pendampingan, Penguatan Lembaga Perlindungan Anak, dan Penguatan Masyarakat dalam Perlindungan Anak serta Respon Kasus atas permasalahan kasus anak. Dan disini terdapat Komponen PKSA dibagi menjadi 5 komponen utama program yaitu:

1. Program Kesejahteraan Sosial Anak Batira (PKS-AB)

2. Program Kesejahteraan Sosial Anak Terlantar/Jalanan (PKS-Antar/PKS Anjal)

3. Program Kesejahteraan Sosial Anak yang Berhadapan dengan Hukum (PKS$\mathrm{ABH})$

4. Program Kesejahteraan Sosial Anak dengan Kecacatan (PKS-ADK)

\footnotetext{
${ }^{41}$ Direktorat, kesejahteraan sosial anak, 2011. Pedoman operasional program kesejahteraan sosial anak. Jakarta : Kementerian Sosial Republik Indonesia.
} 
5. Program Kesejahteraan Sosial Anak dengan Perlindungan Khusus (PKSAMPK)

\section{Peran Satuan Bakti Pekerja Sosial ( Sakti Peksos)}

Peranialahsesuatu yang

diharapkandimilikioleh

yang memilikikedudukandalammasyarakat.Perananialahbagiandaritugasutamayangharusdilaku kan.Pemerananialah proses caraatauperbuatanmemahamiperilaku yang diharapkandandikaitkandengankedudukanseseorang. ${ }^{42}$

Peran (role) merupakan aspek yang dinamis dari kedudukan(status). Artinya seseorang telah menjalankan hak dan kewajibannya sesuai dengan kedudukannya, maka orang tersebut telah melaksanakan sesuatu peran. Keduanya tak dapat dipisahkan karena satu dengan yang lain saling tergantung, artinya tidak ada peran tanpa status dan tidak ada status tanpa peran. Sebagaimana kedudukan, maka setiap orang pun dapat mempunyai macam-macam peran yang berasal dari pola pergaulan hidupnya. Hal tersebut berarti pula bahwa peran tersebut menentukan apa yang diperbuatnya bagi masyarakat serta kesempatan-kesempatan apa yang diberikan masyarakat kepadanya. Peransangat penting karena dapat mengatur perilaku seseorang, di samping itu peran menyebabkan seseorang dapat meramalkan perbuatan orang lain pada batas-batas tertentu, sehingga seseorang dapat menyesuaikan perilakunya sendiri dengan perilaku orang-orang sekelompok. ${ }^{43}$

Sakti Peksos adalah petugas kemanusiaan di bidang pekerjaan sosial anak yang ditetapkan oleh Kementerian Sosial dalam status kerja kontrak karya dengan Direktorat Rehabilitasi Sosial Anak dan merupakan pelaksana langsung dari program-program perlindungan sosial anak dilapangan. Para Sakti Peksos ini berperan sebagai pendampingan sosial dalam rangka perlindungan sosial anak atau permasalahan anak.

Peran Satuan Bakti Pekerja Sosial merupakan sebuah petugas kemanusian dibidang pekerja sosial yang ditetapkan oleh Kementerian Sosial atau Dinas atau Intansi Sosial yang memiliki status kerja kontrak karya dengan Direktorat Kesejahteraan Sosial Anak (PKSA Pusat). Setidaknya ada beberapa peran Satuan Bakti Pekerja Sosial yaitu :

1. Pemercepatan perubahan (enabled).

2. Perantara (broker).

3. Pendidik (educator).

\footnotetext{
${ }^{42}$ Peter Salim dan Yenny Salim, Kamus Bahasa Indonesia Kontemporer, (Jakarta: ModernEnglish Press, 2002), Cet. ke-1, hlm. 1132.

${ }^{43}$ J. Dwi Narwoko dan Bagong Suyanto, Sosiologi Teks Pengantar dan Terapan, (Jakarta:Kencana, 2007), Cet. ke-3, hlm. 158-159.
} 
4. Tenaga ahli (expert).

5. Perencana sosial (social planer).

6. Advokat (advocate).

7. Aktivis (activist). ${ }^{44}$

\section{Teori-Teori Dalam Praktek Sakti Peksos}

Ada beberapa teori yang digunakan dalam praktek Sakti Peksos diantaranya adalah teori sistem, teori belajar sosial, teori pertukaran sosial, teori konflik, teori motivasi, teori ekologi, teori kritis, teori feminis, dan teori konstruksi realitas, dan disini di harapkan sebagai Sakti Peksos harus melaksanakan atau menggunakan teori-teori yang telah ditetapkan, karena sangat penting didalam praktek ketika menghadapi klien, disini saya akan sedikit membahas secara singkat bebrapa teori tersebut yaitu:

1. Teori sistem

Sistem merupakan suatu kerangka yang terdiri dari beberapa elemen/sub elemen/sub sistem yang saling berinteraksi dan saling mempengaruhi. Teori sistem adalah suatu model yang menjelaskan hubungan tertentu antara sub-sub sistem dengan sistem sebagai suatu unit yang bisa saja berupa suatu masyarakat, serikat buruh, dan organisasi pemerintah. Apabila suatu sub sistem tidak berfungsi, maka sistem tidak akan berjalan maksimal atau bahkan tidak berjalan. Intinya, setiap bagian berpengaruh terhadap keseluruhan atau sesuatu tidak dapat ada tanpa keberadaan yang lain. Contoh dari sistem sosial adalah keluarga, di mana anggota-anggota di dalam keluarga disebut sebagai sub sistem atau bagian dari sistem. Dalam pekerjaan sosial makro, kita mengenal masyarakat sebagai suatu sistem.

\section{Teori Social Learning (Pembelajaran Sosial)}

Teori ini mengatakan bahwa orang dapat mempelajari informasi baru dan perilaku dengan cara melihat orang lain (belajar observasional). Konsep dasar dari teori ini adalah bahwa orang-orang dapat belajar melalui observasi atau pengamatan, kemudian dilanjutkan dengan peniruan. Mereka mengubah perilakunya melalui penyaksian terhadap bagaimana orang lain merespon sebuah stimulus tertentu. Teori ini menjelaskan bagaimana kita dipengaruhi dan mempengaruhi lingkungan melalui penguat dan pembelajaran observasional. Contohnya seorang anak menyaksikan temannya sering membaca buku pelajaran, kemudian memperoleh rapot yang bagus. Anak tersebut

\footnotetext{
${ }^{44}$ Adi, Isbandi Rukminto. 2013. Intervensi komunitas:pengembangan masyarakat sebagai upaya pemberdayaan masyarakat. (Edisi Revisi. Jakarta:Rajawali pers).
} 
kemudian memiliki keinginan memperoleh rapot yang bagus pula. Dia pun akhirnya meniru temannya dengan rajin membaca buku pelajaran.

\section{Teori Social Exchange (Pertukaran Sosial)}

Teori ini mengatakan bahwa seseorang berhubungan dengan orang lain karena mengharapkan sesuatu yang memenuhi kebutuhannya. Teori pertukaran sosial pun melihat antara perilaku dengan lingkungan terdapat hubungan yang saling mempengaruhi. Di dalam hubungan tersebut, tedapat unsur imbalan, pengorbanan, dan keuntungan.

Cakupan pekerja sosial makro antara lain salah satunya adalah organisasi. Organisasi merupakan suatu wadah atau tempat terjadinya kegiatan bersama untuk mencapai tujuan bersama dan memiliki visi dan misi untuk menampung dan menyalurkan pendapat atau pikiran yang berbeda. Unsur-unsur organisasi adalah orang-orang, kerjasama, tujuan bersama, peralatan atau sarana, lingkungan, dan kekayaan alam. Teori organisasi merupakan studi yang memandang suatu organisasi, baik dari segi fungsi maupun struktur, dengan meninjau pendekatan untuk mencari solusi dari permasalahan dalam suatu organisasi, di mana seluruh pelaku dalam organisasi saling berinteraksi dan saling mempengaruhi untuk mencapai tujuan bersama.

Teori ini menolak anggapan bahwa masyarakat ada dalam situasi stabil dan tidak berubah. Masyarakat selalu dilihat dalam suatu kondisi tidak seimbang atau tidak adil, dan keadilan dapat dicapai dengan penggunaan kekuatan revolusi terhadap kelompokkelompok yang berkuasa. Masyarakat juga terbentuk dari individu-individu yang bersaing untuk sumber daya yang terbatas.

\section{Teori Motivasi}

Motivasi pada dasarnya merupakan alasan untuk bertindak atau dorongan manusia untuk mencapai tujuannya. Motivasi juga merupakan suatu proses untuk mempengaruhi orang lain untuk melakukan sesuatu sesuai dengan yang kita inginkan. Teori motivasi menjelaskan bagaimana alasan bisa muncul pada diri seseorang. Seseorang dapat bertindak jika dia telah memiliki motivasi.

5. Teori Ekologi

Teori ini menekankan bahwa lingkungan sangat berpengaruh terhadap perkembangan. Ada lima sistem dalam teori ini, yaitu mikrosistem, mesosistem, ekosistem, makrosistem, dan kronosistem. Mikrosistem merupakan tempat di mana seseorang hidup, misalnya mikrosistem seorang anak meliputi keluarga, guru, teman 
sebaya, dan lain-lainnya yang sering ditemui anak. Dalam mikrosistem, terjadinya interaksi, misalnya anak dengan orang tua, anak dengan guru, dan sebagainya.

\section{Teori Kritis}

Teori ini membahas tentang emansipasi dan penindasan. Tujuan daripada teori ini adalah untuk menghilangkan segala bentuk dominasi dan penindasan, serta mendorong adanya kebebasan dan keadilan. Teori ini mempertanyakan sebab-sebab yang mengakibatkan penyelewengan-penyelewengan dalam masyarakat.

\section{Teori Feminis}

Secara umum, permasalahan mengenai gender muncul karena posisi kaum wanita yang dianggap lebih rendah dari kaum pria. Posisi wanita dalam kehidupan sosial sering dianggap lebih rendah dengan posisi laki-laki. Laki-laki dianggap bekerja dalam posisi yang lebih menguntungkan daripada wanita karena laki-laki bekerja untuk mendapatkan upah, sedangkan wanita bekerja mengurus rumah tangga tanpa mendapatkan upah apapun

\section{Teori Reality Construction (Konstruksi Realitas)}

Teori ini mengandung pemahaman bahwa realitas atau kenyataan dibangun secara sosial. Realitas merupakan hasil ciptaan manusia melalui kekuatan konstruksi sosial terhadap dunia sosial di sekelilingnya. Realitas sosial tercipta, dipertahankan, dan diubah melalui tindakan dan interaksi manusia. ${ }^{45}$

Jadi, teori sangat penting bagi pekerja sosial profesional dalam melaksanakan praktek pekerjaan sosial. Tanpa teori, praktek hanya didasarkan atas alasan-alasan yang kebetulan. Sementara, masalah sosial yang ada di masyarakat ini bukanlah suatu hal yang dieksperimen pemecahan masalahnya, apalagi objek dalam masalah sosial adalah manusia. Jika pemecahan masalah tidak didasari dengan praktek, maka pemecahan masalah itu bisa jadi penyebab masalah baru. Oleh karena itu, teori dan praktek haruslah seimbang, karena teori merupakan pedoman untuk memudahkan berjalannya praktek.

Setelah peneliti melakukan wawancara kepada salah satu Sakti Peksos yaitu Pak Minardi beliau mengatakan bahwa sebagai Sakti Peksos harus berlandaskan dengan teori setiap dalam pekerjaan, karena Sakti Peksos tidak bisa melangkah tanpa dasar atau kekuatan untuk menyelesaikan masalah tertentu, jadi teori-teori peksos sering kita gunakan didalam aplikasi lapangan ketika kita dalam penanganan suatu kasus. Contoh

\footnotetext{
${ }^{45}$ http://ginakesos.blogspot.co.id/2012/09/
} 
kasus yang pernah dihadapi Pak Minardi seorang klien yang bermasalah dengan perekonomian untuk kebutuhan hidupnya, yang menyebabkan mereka tinggal di suatu ruangan kecil (gubuk kecil) ada bapak, ibu, dan anak dan mereka tidur bersebelahan, ketika orang tua anak ini melakukan hubungan layaknya suami istri, sang anak melihat langsung orang tuanya melakukan hal tersebut, dan itulah yang menimbulkan kekhawatiran bahwa kedepannya anak akan meniru dan bahkan mungkin akan mempraktekkan dengan anak-anak kecil di sekelilingnya.

Didalam melaksanakan tugas sebagai Sakti Peksos ini terutama dalam contoh kasus tersebut kendala yang dihadapi oleh Pak Minardi sendiri adalah yang mana anak ini sudah kecanduan keinginannya yang sangat besar terhadap apa yang dia lihat dari orang tuanya, jadi Pak Minardi sendiri sangat kesulitan didalam pemulihan psikisnya ataupun pola pikirnya, karena dalam diri anak sudah timbul keingintahuan yang sangat besar.

Jadi untuk mengatasi hal tersebut teori yang tepat untuk mengatasinya yaitu Teori Social Learning (Pembelajaran Sosial), yang intinya teori ini adalah mengamati, meniru dan mempraktekkan, jadi Pak Minardi melakukan implementasi teori ini dengan beberapa langkah atau proses awal yang dilakukannya yaitu sebagai berikut :

1. Membangun komunikasi yang baik dengan pihak pemerintah dusun, paling tidak Rt (bila kasus sudah di ketahui) jika belum, langsung saja membangun komunikasi yang baik dengan keluarga si anak untuk mengetahui kronologi kasus dan kedetelan internal keluarga tersebut.

2. Melihat situasi apakah dampak dari kasus tersebut sudah parah atau mengakibatkan anak melakukan tindakan yang tidak baik (tidak sewajarnya) atau kasus tersebut masih biasa-biasa saja, dalam artian anak masih belum paham dan mengetahui apa yang sebenarnya yang dilakukan oleh orang tuanya tersebut.

3. Setelah melakukan dua hal tindakan tersebut, perlunya kroscek ke lingkungan sekitar (terutama tetangga) terkait keadaan sehari-hari mereka, namun jangan sampai detail dan menceritakan terkait kasus, tetapi cukup mengetahui bagaimana kehidupan sosial keluarga si anak dan bagaimana orang tuanya mendidik anakanaknya.

4. Dari tiga sumber informasi tersebut, kalau memang anak terkatagori parah, Sakti Peksos sekiranya bekerja sama dengan psikolog atau dokter tenaga medis supaya untuk mengatasi hal tersebut, karena di sini Sakti Peksos bterkadang pendampingan 
dalam hal penanganan psikisnya belum 100\% menguasai, tetapi kalau Sakti Peksos merasa mampu akan lebih baik di dampingi untuk penguatan psikisnya terkait bahaya pornografi (tindakan seksual yang belum seharusnya dia lakukan). Namun bila dampak terhadap anak baru beberapa kali melihat atau belum sampai parah, perlunya penguatan dan pendampingan yang maksimal oleh Sakti Peksos sendiri sampai anak menghilangkan rasa keingintahuan nya.

5. Terkait dengan orang tuanya, sekiranya Sakti Peksos bisa memberikan arahan dan pengetahuan terkait dampak buruknya terhadap anak apabila sering melihat hal tersebut, bila perlu dokter atau tenaga medis atau psikolog yang ikut bersama Sakti Peksos untuk menjelaskannya, agar permasalahan tidak berlanjut dan bisa diatasi sebagaimana mestinya.

6. Memberikan gambaran bahwa diluar sana banyak anak-anak yang berprestasi karena rajin sekolah, membaca buku, unggul dalam seni dan lain-lain, serta itu anak juga harus kita support dan terus kita dorong untuk mengarah kepada hal-hal yang positif agar nantiknya anak ini memiliki visi misinya kedepan lebih mempunyai tujuan yang positif lagi.

Jadi begitulah proses awal yang di lakukan Pak Minardi di dalam menangani kasus pada anak tersebut, di karenakan Sakti Peksos masih kurang ilmu dan pemahaman yang terkait dengan penyelesain kasus traumatis seks pada klien, jadi langkah yang di laksakan bekerjasama dengan jejaring seperti dokter, psikolog, atau tenaga medis untuk membantu dalam proses pendampingannya, setelah berjalannya waktu anak pun mulai bisa menghilangkan rasa traumatisnya, di samping itu barulah penerapan pendampingan dengan teori social learning di laksanakan setelah psikis klien ini tadi membaik dan bisa menerima atas masukan didikan untuk lebih baik lagi kedepannya oleh Sakti Peksos ini tadi.

Proses pendampingan social learning pun berjalan dengan lancar, sehingga klien pun bisa lebih baik lagi di dalam bertindak, setelah di pastikan klien sudah bisa di kembalikan kepada orang tuanya, Sakti Peksos pun mengembalikannya kepada orang tua klien, namun di samping itu Sakti Peksos tetap harus melakukan monitoring terhadap klien yang telah di kembalikan kepada orang tuanya, sampai benar-benar klien sembuh atau sampai klien tidak perlu bantuan lagi. 


\section{Penutup}

Program Kesejahteraan Sosial Anak adalah upaya yang terarah, terpadu dan berkelanjutan yang di lakukan pemerintah dan masyarakat dalam bentuk pelayanan sosial untuk memenuhi kebutuhan dasar anak meliputi subsidi kebutuhan dasar, aksebilitas pelayanan sosial, penguatan orang tua atau keluarga dan lembaga kesejahteraan sosial anak. Program Kesejahteraan Sosial Anak (PKSA) menjadi prioritas nasional Kementrian Sosial RI untuk mewujudkan pemenuhan hak dasar anak dan perlindungan terhadap anak dari penelantaran, eksploitasi dan diskriminasi.

Namun kesejahteraan sosial anak sepenuhnya belum terlayani, seperti hak memperoleh kebutuhan dasar yaitu (sandang, pangan, papan). Padahal anak adalah penentu majunya suatu negara yang dapat dilihat dari kondisi anak sekarang ini, bila kondisi anak sekarang ini sudah mulai tidak terlayani kebutuhannya, maka majunya suatu negara tidak akan berkembang, melainkan akan melahirkan generasi-generasi perusak bangsa. Dengan hal tersebut, maka pelayanan hak anak harus ditingkatkan supaya nilai gunanya tinggi.

Dan kita ketahui bahwa Program Kesejahteraan Sosial anak (PKSA), yang mana program ini telah di laksanakan oleh dinas sosial kabupaten Gunung Kidul yang dalam pelaksanaannya tidak lepas dari peran seorang pekerja sosial. Dalam program kesejahteraan sosial anak ini tidak memisahkan anak dengan keluarga, melainkan anak tinggal bersama keluarga, jadi model pendampingan yang di lakukan pekerjaan sosial dari dinas sosial ini bersifat insindental (sewaktu-waktu) bila di perlukan untuk mendampingi klien.

Jadi dari hasil pembahasan dan hasil penelitian di atas menerangkan dengan adanya pendampingan yang di laksanakan Sakti Peksos terhadap klien yang bermasalah dengan kasus traumatis seks, Sakti Peksos bekerja sama dengan beberapa pihak seperti dokter, psikolog, atau tenaga medis untuk membantu dalam proses pendampingannya, karena sebelum klien di berikan pendampingan social learning, langkah awal bagaimana klien ini pola pikirnya atau psikisnya bisa kembali normal kembali, agar nanti di dalam proses pendampingan social learning oleh sakti peksos itu sendiri bisa berjalan dengan baik, oleh sebab itu di dalam proses pelayanan terhadap klien, Sakti Peksos harus bekerja sama dan membangun jejaring yang luas agar mempermudah proses penanganan terhadap klien yang bermasalah. 


\section{Daftar Pustaka}

Adi, Isbandi Rukminto. 2013. Intervensi komunitas:pengembangan masyarakat sebagai upaya pemberdayaan masyarakat. (Edisi Revisi. Jakarta:Rajawali pers).

Direktorat, kesejahteraan sosial anak, 2011. Pedoman operasional program kesejahteraan sosial anak. Jakarta : Kementerian Sosial Republik Indonesia.

J. Dwi Narwoko dan Bagong Suyanto, Sosiologi Teks Pengantar dan Terapan, (Jakarta:Kencana, 2007), Cet. ke-3, hlm. 158-159.

Keith Davis, Jhon W. Newstrom, Perilaku dalam Organisasi, (Jakarta: Gelora Aksara Pratama), hlm 51

Miftahul Huda, Pekerjaan Sosial Dan Kesejahteraan Sosial, (Yogyakarta Pustaka Pelajar, 2009), Hlm, 3

Nurvidya dan Wongkaren, Pedoman Penanganan Masalah Sosial, (Bandung Sinar Bari Algesindo, 1997) HLM.3

Pedoman Operasional Program Kesejahteraan Sosial Anak (PKSA), Direktorat Kesejahteraan Sosial Anak, Direktorat Jenderal Rehabilitas Sosial, Kementerian Sosial RI,Hlm VI

Peter Salim dan Yenny Salim, Kamus Bahasa Indonesia Kontemporer, (Jakarta: ModernEnglish Press, 2002), Cet. ke-1, hlm. 1132

Soerjono Soekanto, Sosiologi Suatu Pengantar, (Jakarta: PT. Raja Grafindo Persada, 1996),Cet. ke-22, hlm. 269

Sugiyono, Memahami Penelitian Kualitatif, h.52

Undang-Undang Rebuplik Indonesia Nomor 4 Tahun 1979 tentang Kesejahteraan Anak.

Undang-Undang Republik Indonesia Nomor 23 Tahun 2002 tentang Perlindungan Anak, pasal 1 ayat 3

Undang-Undang Republik Nomor 11 Tahun 2009 Tentang Kesejahteraan Sosial, Hlm, 3

Veitzhal Rivai, Deeddy Mulyadi, Kepimpinan dan Perilaku Organisasi, (Jakarta: PT RajaGrafindo, 2012), hlm. 156

Wibowo, Perilaku dalam Organisasi, (Jakarta: PT. RajaGrafindo Persada, 2013), hlm. $169-170$ 
$\underline{\text { http://dinsos.jogjaprov.go.id/program-kesejahteraan-sosial-anak/ }}$

http://ginakesos.blogspot.co.id/2012/09/

http://pksa.kemsos.go.id 